\title{
Determinants of Participation in Non-farm Activities among Rural Farm Households in Ambo District of West Shoa Zone, Oromia Region, Ethiopia
}

\author{
Zewdu Adefris $^{1^{*}} \quad$ Birhanu Woldeyohannes ${ }^{2}$ \\ 1.Department of Development Economics, Ethiopian Civil Service University, PO box 5648, Addis Ababa, \\ Ethiopia \\ 2.Addis Ababa Transport Bureau Technical and Financial Capacity Building Director, Ethiopia
}

\begin{abstract}
This study examined the determinants of non-farm economic activities participation decisions among rural farm households in Ambo district of West Shoa zone of Oromia region, Ethiopia. The research design adopted in this study was cross-sectional field survey from which a total of 300 rural farm households drawn. Descriptive statistics and logistic regression model were applied to investigate the effect of various factors on the decision to participate in non-farm economic activities. The logistic results show that gender, marital status of household head, dependency ratio, skill, access to credit and distance to the nearest market were found to be the key factors that significantly influenced rural farming household's decisions to participate in non-farm activities. Women and married headed rural farm households were more likely to participate in non-farm activities. Transferable skill and access to credit also have positive influence on rural farm household decision to participate in non-farm activities. High dependency ratio and a long distance from the house to nearest market have strong negative effect on the decision to participate in remunerative non-farm activities. According to the descriptive result, the major non-farm economic activities that help rural households in the study area comprise selling of foods and drinks, retail shop, selling of wood and charcoal, trade in grain general, weaving, boutique, and craft work. The study has also identified factors that lead households to participate in non-farm activities. They include low income from farming activities, land inadequacy, soil fertility or productivity, growing family size, and increased opportunities. Thus, while this study is not advocating for non-farm economic activities as a substitute to farming, non-farm work could be a reliable complement to farming activities. Policies that aim to increase the non-farm work participation decisions of family members should take into consideration the difference in responses to the various factors that affect the non-farm activities decisions of rural farm households.
\end{abstract}

Keywords: Determinants, Participation, Non-farm activities, Rural Households, Logit Model

DOI: $10.7176 / \mathrm{JEP} / 12-4-04$

Publication date: February $28^{\text {th }} 2021$

\section{Introduction}

In developing countries, non-farm activities play a more and more important role in sustainable development and poverty reduction in rural areas. Non-farm activities can influence the rural economy through various channels. First, non-farm employment ${ }^{1}$ reduces the pressure on the demand for land in poor areas. Consequently, non-farm activities can contribute to breaking the vicious cycle of "poverty - extensive cultivation - ecological deterioration - poverty". Second, the income obtained from non-farm activities can significantly increase total household income and hence enhance the investment capacity in farm activities. It can also mitigate income fluctuations and enable the adoption of some more profitable but "risky" agricultural technologies, which favour the transformation of traditional agriculture to modern agriculture. Third, non-farm income is often a source of savings, which plays an important role in poverty reduction. The households that diversify their income by participating in non-farm activities are more capable of overcoming negative shocks.

Like in other developing countries, agriculture in Ethiopia is a dominant sector where about $85 \%$ of the population earns their livelihood from agriculture. Given the increasing population growth in rural Ethiopia and the relatively limited quantity of cultivable land, the agricultural income per capita has been low. In addition to land scarcity, agricultural production seasonal and, therefore, rural labour cannot be employed throughout the year which needs to widely develop non-farm activities [16].

In such a situation, non-farm sectors can play an important role in absorbing the surplus agricultural labour, in enhancing the income of farmers, and in reducing rural poverty. Thus efforts to promote rural development, which includes progress both in farm and non-farm activities, will help to bring better days in Ethiopia. Nonfarm activities provide not only alternative sources of income and employment for the rural poor but also stimulate agricultural production.

Many rural households are not undertaking non-farm activities due to lack of asset to start the business.

\footnotetext{
${ }^{1}$ Non-farm employment refers to employment not related to farming activities.
} 
Others are confined with less important activities that cannot allow them to grow out of poverty. Thus, identification of the factors determining access and income from non-farm activities is crucial for policy makers to inform and adjust policies in the rural domain [15].

Several studies have investigated the factors that most influence rural household participation in non-farm activities. For example in the study by [11], education level, availability of land, and access to economic centres and credit were the most important factors in determining the number of households that participate in a particular rural local labour market and the share of labour income in total cash income.

In the area of study, little study has been conducted to examine the determinants of rural households' participation decisions in remunerative non-farm activities. Hence, following the increased participation of rural household in non-farm activities, this research was intended to analyze the determinants of involvement in the non-farm activities and describes the characteristics of non-farm activities in Ambo district of West Shoa Zone, Oromia Region, Ethiopia.

The general objective of the study is to analyze the determinants of participation in remunerative non-farm activities among rural farm households in Ambo district of West Shoa Zone, Oromia Region, Ethiopia. The specific objectives are:

- To examine the determinants of participation in non-farm activities among rural farm households in the study area;

- To identify the types of non-farm activities that the rural households tend to participate;

- To identify the main reasons for participating in non-farm activities.

\section{Review of Related Literature}

Non-farm sector has a potential contribution in the livelihood of rural household as it provides alternative source of rural income generating activities which improves distribution of income, contributes to the growth of rural economy and strengthen poverty alleviation efforts [11].

Several studies have investigated the factors that most influence rural household participation in non-farm activities. According to [1] in a study of income strategies among rural household in Mexico showed that level of education has positive and significant effects on the tendency to participate in non-farm economic activities and influences participation in more lucrative activities. There are mixed results with regard to the influence of gender on the level of participation in non-farm activities. [8] found that the engagement in the non-farm sector is higher for men than for women. [7] found that increased of participation of women in non-farm activities was often as a secondary activity, with agriculture being the primary economic activity.

Household size plays a significant role in influencing farm household participation in non-farm activities. An empirical investigation by [12] has shown that a large family size increases the participation in non-farm activities. According to [8], high dependency ratio reduces participation rate and amount of earnings.

According to [4], farmers with better skills such as carpentry and masonry had an advantage over those with limited or no skills at all and that relatively wealthy ones had greater opportunities in undertaking the most remunerative non-farm activities. The study conducted by [13] also indicated that training in entrepreneurship and management, technology development and dissemination among crafts people, the need for cooperativesupported activities and the expansion of social and physical infrastructure were essential to maximize the benefits from non- and off-farm activities.

[9] pointed out a negative relation between larger landholdings and participation in non-farm activities. [14] in Latin America identified that access to credit another proxy to availability of finance recognized to increase income and participation in non-farm activities.

Locations in which non-farm activities are undertaken play an important role in driving the participation in, and success of, non-farm activities. [7], found that there is a positive correlation between involvement in nonfarm activities and household location. Households located in remote rural areas were less likely to be employed in the non-farm sector than those close to urban areas. In a related study by [7], found that in Bangladesh, proximity to large cities was an important determinant of non-farm income levels. These findings showed that the likelihood of being engaged in high-return non-farm activities increases with proximity to markets. The empirical results stress the need to improve rural-urban linkages to stimulate the growth in high return wage and self-employment non-farm activities.

\section{Methodology}

\subsection{Conceptual Framework}

The model employed in this study is the one suggested by [6], where farm households allocate their time to individual activities including non-farm employment. A farm household is assumed to maximize a utility function defined over consumption of goods $Q$ and leisure, $H$, i.e., $=U(Q, H)$. Utility is maximized subject to time, budget, production, and non-negativity constraints. The time constraint is $T=L_{1}+L_{2}+H_{2}$ where $T$ 
is total time endowment, $L_{1}$ and $L_{2}$ are respectively time allocated to farm work and non-farm work, and $H$ is leisure as defined above. The budget constraint on household cash income can be expressed as

$$
P Q=p_{1} y_{1}-w_{1} L_{1}+w_{2} L_{2}+R \text {, }
$$

where $P$ is the price for consumption good purchased in the market, $w_{1}$ and $w_{2}$ denote returns to labour from farm work and non-farm work, respectively, $y_{1}$ and $p_{1}$ are annual quantity of farm output produced and sold and price for farm output, respectively and $R$ represent non-labor income.

The first order condition for optimal time allocation for farm work, non-farm work and leisure is given as $\frac{\partial U}{\partial L_{t}}=\frac{w_{t} \partial U}{\partial Q}-\frac{\partial U}{\partial L}$ work and non-farm work:

$W_{i}=\left(\frac{\partial U}{\partial L}\right) /\left(\frac{\partial U}{\partial Q}\right)$ functions for farm work and non-farm work can be derived as

$$
\begin{aligned}
& L_{1}=L_{1}\left(w_{1}, w_{2}, p_{1}, p_{2} ; Z\right) \\
& L_{2}=L_{2}\left(w_{1}, w_{2}, p_{1}, p_{2}, R ; Z\right)
\end{aligned}
$$

As noted by Huffman (1991), a positive number of non-farm hours will be observed for an individual $i$, if the potential market wage $\left(w_{t}^{m}\right)$ is greater than the reservation wage $\left(w_{t}^{r}\right)$. Thus, $L_{t}=1_{\text {if }} w_{t}^{m}>w_{t}^{r^{r}}$ and $L_{t}=0$ if $w_{t}^{m} \leq w_{t}^{r}$. Thus, reservation wage is key element in the decision of participation in non-farm work. The reservation wage is an endogenous variable, explained by the other exogenous variables in the model such as, output and costs of production, fixed farm factors, individual and household characteristics. Thus, variables that raise the reservation wage reduce the probability of non-farm participation, while variables that raise the market wage rate, increase the probability of seeking non-farm employment [2].

\subsection{Empirical Model Specification}

Regression models in which the dependent variable is dichotomous can be estimated by linear probability model (LPM), logit or probit models. Although LPM is simple method, it is not logically attractive model in that it assumes that the conditional probability increases linearly with the value of explanatory variables. Usually a choice has to be made between logit and probit models. According to [5], a logistic distribution has advantages over the others in the analysis of dichotomous outcome variable in that it is extremely flexible and easily used model from mathematical point of view and results in meaningful interpretation. In view of this, the logistic function was employed to analyze the determinants of participation in cash-oriented non-farm activities among rural farm households in the study area.

As stated above, the differential wages are not observable. What is observed is the decision to participate, or not to participate in non-farm economic activities. This decision can be specified as an index function with unobserved variable $L_{i}^{*}$. Such that

$$
\begin{aligned}
L_{i}^{*}=\beta Z_{i}^{s}+\mu_{i} \\
L_{t}=1 \text { if } L_{t}^{*}>0 \\
L_{t}=0 \text { if } L_{t}^{\text {w }} \leq 0
\end{aligned}
$$

Where; $\quad Z_{i}$ denotes a vector of explanatory variables, and

$\mu_{t}$ is the random disturbance term.

Based on theoretical and empirical considerations, we specify the following model for non-farm employment participation:

$$
\begin{aligned}
\text { Nfarm }= & \beta_{0}+\beta_{1} \text { sexhead }+\beta_{1} \text { agehead }+\beta_{3} \text { agesqu }+\beta_{4} \text { married }+\beta_{5} \text { educihead } \\
+ & \beta_{6} \text { hhsize }+\beta_{7} \text { depratio }+\beta_{8} \text { skill }+\beta_{9} \text { acceredit }+\beta_{10} \text { hhtand }+\beta_{11} \text { irrigace } \\
& +\beta_{12} \text { dismkt }+\beta_{13} \text { disroad }+\varepsilon
\end{aligned}
$$

The dependent variable is individual participation in remunerative non-farm activities ( $N$ farm) and takes the value 1 if the household participates in remunerative non-farm activities, zero otherwise. The code, definition and expected sign of the explanatory variables are presented in Table 1.

\footnotetext{
${ }^{1}$ The reservation wage for non-farm work is the marginal value of the individual's time when all of it is allocated to farm and leisure.
} 
Table 1: Codes, definition and expected sign of the explanatory variables

\begin{tabular}{|l|l|c|}
\hline \multicolumn{1}{|c|}{$\begin{array}{c}\text { Variable } \\
\text { Codes }\end{array}$} & \multicolumn{1}{|c|}{ Definition and Measurement } & $\begin{array}{c}\text { Sign } \\
(+/-)\end{array}$ \\
\hline sexhead & 1 if the household head is male, 0 otherwise & $+/-$ \\
\hline agehead & Continuous variable refers to the age of the household head & + \\
\hline agesqu & Continuous variable, square of the household head age & - \\
\hline married & 1 if the household head is married, 0 otherwise & + \\
\hline educ8head & 1 if the household head is at least primary school complete, 0 otherwise & + \\
\hline hhsize & Continuous variable, household size in adult equivalence & + \\
\hline depratio & $\begin{array}{l}\text { Continuous variable of the ration of (children under age of 15 and old age of above } \\
65 \text { to active labor force) }\end{array}$ & $+/-$ \\
\hline skill & 1 if the household head possess special/transferable skill, 0 otherwise & + \\
\hline accredit & 1 if household head with access to credit, 0 otherwise & + \\
\hline hhland & Continuous, size of farms owned in hectare & - \\
\hline irrigacc & 1 if the household has access to irrigation, 0 otherwise & - \\
\hline dismkt & Continuous, distance from house to nearest market centre measured by kilometer & - \\
\hline disroad & Continuous, distance from house to main road measured by kilometer & - \\
\hline
\end{tabular}

\subsection{Data set}

Primary and secondary data were the main source of data in this study. In order to obtain the primary data, a cross sectional field survey was adopted using structured questionnaire. Accordingly, household interview was conducted to a total of 300 rural farm households: 150 households were identified as participant and 150 as nonparticipant in remunerative non-farm activities. Secondary data was obtained through extensive literature review from various local and international reports and publications. The documents which were reviewed involve journals, books, official reports and previous researches.

\section{Results and Discussions}

\subsection{Descriptive statistical results and discussions}

The descriptive statistics was run to observe the distribution of the independent variables. The individual/household characteristics, household assets, location characteristics, and access to infrastructure characteristics of participants and non-participants of non-farm activities are analyzed.

As shown in Table 2, out of 300 sampled households, $87.67 \%$ were male and $12.33 \%$ were female headed households. The result further indicated that $81.33 \%$ of participant of non-farm activities were male whereas, the corresponding figure for female households was $18.67 \%$. Male respondents comprise $94 \%$ of non-participant of non-farm activities and the remaining $6 \%$ were female. Moreover, the chi-square test revealed significant difference on the non-farm activities decisions of farm households regarding gender of sample households and found to be significant at $1 \%$ probability level.

Table 2: Distribution of sample households by gender, marital status and level education

\begin{tabular}{|c|c|c|c|c|c|c|c|}
\hline \multirow[t]{2}{*}{ Variables } & \multicolumn{2}{|c|}{ Participant } & \multicolumn{2}{|c|}{ Non-participant } & \multicolumn{2}{|c|}{ Total } & \multirow{2}{*}{$x^{2}$} \\
\hline & Freq. & $\%$ & Freq. & $\%$ & Freq. & $\%$ & \\
\hline Gender & & & & & & & $11.13^{* * *}$ \\
\hline Male & 122 & 81.33 & 141 & 94 & 263 & 87.67 & \\
\hline Female & 28 & 18.67 & 9 & 6 & 37 & 12.33 & \\
\hline Marital Status & & & & & & & $11.06^{* *}$ \\
\hline Married & 121 & 80.67 & 139 & 92.67 & 260 & 86.67 & \\
\hline Single & 5 & 3.33 & 4 & 3 & 8 & 2.67 & \\
\hline Widowed & 15 & 10 & 7 & 4.67 & 22 & 7.33 & \\
\hline Divorced & 9 & 6 & 1 & 0.67 & 10 & 3.33 & \\
\hline Level of Education & & & & & & & 7.62 \\
\hline Illiterate & 29 & 19.33 & 29 & 19.33 & 58 & 19.33 & \\
\hline Can read and write & 11 & 7.33 & 24 & 16 & 35 & 11.67 & \\
\hline $\begin{array}{l}\text { Household head with } \\
\text { primary education }\end{array}$ & 75 & 50 & 57 & 38 & 132 & 44 & \\
\hline $\begin{array}{l}\text { Household head with } \\
\text { secondary education }\end{array}$ & 35 & 23.33 & 40 & 26.67 & 75 & 25 & \\
\hline
\end{tabular}

$* * *, * *$ and $*$ indicates significant at $1 \%, 5 \%$ and $10 \%$ probability level, respectively.

Source: Compute from own survey, 2017. $\%=$ percent, Freq.= frequency 
Distribution of the total sample households by marital status indicates that married, single, widowed and divorced households accounted for about 86.67, 2.67, 7.33 and $3.33 \%$, respectively. This shows that most of the sampled household heads in the study area are married (86.67\%). Moreover, the chi-square test showed that there was statistically significant difference between marital status of non-participant and participants (at 5\% level).

The distribution of total sample respondents in terms of literacy level has shown that $19.33 \%$ were illiterate, $11.67 \%$ could read and write, $44 \%$ had attended primary education, and the remaining $25 \%$ had attended secondary education. The discussion with respondent indicated that the non-farm activities undertaken in the surveyed areas were small scaled which does not require higher level of education. However, the chi-square test revealed that there was no statistically significant difference between educational level of participant and nonparticipants (Table 2).

Table 3 shows that the mean age of the total sample households was found to be 42.41 years with standard deviation of 11.56 years. The mean age of households participate in non-farm activities was 40.24 years and that of non-participant households was 44.58 years. The t-test revealed that the mean age of households was significantly different at $1 \%$ probability level between participant and non-participant households. This implied as the age of household head increases, the probability of a household to be participated in non-farm activities decreases. Besides, the mean square of household heads' age of the total sample households was found to be 1931.9 with standard deviation of 1069.9. The t-test revealed that the mean square of household heads' age was significantly different at $1 \%$ probability level between participant and non-participant households in non-farm economic activities.

The mean household size in adult equivalent was found to be 4.70 and 4.82 for participant and nonparticipant households respectively and their mean difference was -0.12 . The overall mean household size for sampled households in adult equivalent was 4.76 with standard deviation of 1.69 . However, the mean comparison of two groups in terms of mean household size in adult equivalent revealed that there was no statistically significant disparity between participant and non-participant sample household groups.

The overall average dependency ratio for the sample households is about 0.73 . The mean dependency ratio for participant was 0.65 while, the corresponding figure for non-participant households was 0.81 . The statistical analysis showed significant difference in mean dependency ratio at $10 \%$ probability level between participant and non-participant sample household groups.

Table 3: Distribution of sample households by age, household size, and dependency ratio

\begin{tabular}{|lccccccc|}
\hline Variables & \multicolumn{2}{c}{ Participant } & \multicolumn{2}{c}{ Non-participant } & \multicolumn{2}{c|}{ Total } & \multirow{2}{*}{ t-value } \\
\cline { 2 - 8 } & Mean & SD & Mean & SD & Mean & SD & \\
\hline Age of household head & 40.24 & 9.96 & 44.58 & 12.63 & 42.41 & 11.56 & $-3.30^{* * *}$ \\
\hline Square of household heads' age & 1717.8 & 857.5 & 2145.9 & 1212.4 & 1931.9 & 1069.9 & $-3.53^{* * *}$ \\
\hline Household size in AE & 4.70 & 1.63 & 4.82 & 1.75 & 4.76 & 1.69 & -0.62 \\
\hline Dependency ratio & 0.65 & 0.73 & 0.81 & 0.85 & 0.73 & 0.8 & $-1.75^{*}$ \\
\hline
\end{tabular}

$*, * * *$ indicate significant at $10 \%$ and $1 \%$ probability level, respectively.

Compute from own survey, 2017. SD = standard deviation. Source:

The mean land holding size in hectare of the sample households in the study area is depicted in Table 4 below. Including landless households, the mean land holding size for participant and non-participant sample households was found to be 1.51 and 1.92 hectare, respectively. The overall mean of land holding size of sample households was 1.71 hectare per household with standard deviation of 1.39 hectare. However, the statistical analysis showed that there was no a statistically significant disparity between participant and non-participant respondents with respect to land holding size.

Table 4: Distribution of sample households by size of farm owned in hectare

\begin{tabular}{|c|c|c|c|c|c|c|c|}
\hline \multirow[t]{2}{*}{ Variables } & \multicolumn{2}{|c|}{ Participant } & \multicolumn{2}{|c|}{ Non-participant } & \multicolumn{2}{|c|}{ Total } & \multirow[t]{2}{*}{ t-value } \\
\hline & Mean & SD & Mean & SD & Mean & $\mathrm{SD}$ & \\
\hline Farm size & 1.51 & 1.13 & 1.92 & 1.58 & 1.71 & 1.39 & -2.59 \\
\hline
\end{tabular}

Source: Compute from own survey, 2017

As presented in Table 5, out of the total sampled households, $15.33 \%$ of them had possessed special skill. The proportions of participant sample respondents who possessed skill were $26.67 \%$, while those of nonparticipant respondents were $4 \%$. The chi-square analysis showed that there was a statistically significant disparity between participant and non-participant respondents with respect to possession of transferable skill, at $1 \%$ level of significance.

Out of the total sampled households, $20.33 \%$ had obtained credit from different credit sources during the survey period. The proportion of sample households that received credit (loan) was $46.15 \%$ for participant and $0.59 \%$ for non-participant, respectively. The chi-square analysis revealed that there was statistically significant disparity between participant and non-participant households regarding access to credit and found to be 
significant at less than $1 \%$ probability level.

Out of the total sampled households, only $9 \%$ of them were found to practice crop cultivation under irrigation scheme. However, the chi-square analysis revealed that there was no statistically significant difference between participant and non-participant households regarding access to irrigation.

Table 5: Distribution of households by possessing skill, access to credit and irrigation (\%)

\begin{tabular}{|lccccccc|}
\hline Items & \multicolumn{2}{c}{ Participant } & \multicolumn{2}{c}{ Non-participant } & \multicolumn{2}{c|}{ Total } & \multirow{2}{*}{${ }^{2}$} \\
\cline { 2 - 7 } & Yes & No & Yes & No & Yes & No & $\chi^{* * *}$ \\
\hline Special skill & 26.67 & 73.33 & 4 & 96 & 15.33 & 84.67 & $29.68^{* * *}$ \\
\hline Access to credit & 46.15 & 53.85 & 0.59 & 99.41 & 20.33 & 79.67 & $60.92^{* * * *}$ \\
\hline Access to irrigation & 4 & 96 & 14 & 86 & 9 & 91 & 3.16 \\
\hline
\end{tabular}

*** indicates significant at $1 \%$ probability level.

Source: Compute from own survey, 2017.

Table 6 shows that the average distance of the total sampled households' home from the nearest market place was $9.87 \mathrm{~km}$ with standard deviation of $4.89 \mathrm{~km}$. On average participants were located about $7.54 \mathrm{~km}$ distances whereas non-participants were about $12.22 \mathrm{~km}$ far away from the nearest market. The result also revealed that mean difference of distance to market was significant at $1 \%$ level of significance. This indicates that participants lived near to the nearest market place as compared to non-participants. This could have motivated the rural households to participate in non-farm activities than those who lived far from the nearest market.

The survey result revealed that the average distance of the total sampled households' home from main roads was 2.93 kilometre with standard deviation of 2.61 kilometre. However, the chi-square analysis revealed that there was no statistically significant difference between participant and non-participant households regarding distance from the main road.

Table 6: Distribution of sample households by distance to markets and main road

\begin{tabular}{|c|c|c|c|c|c|c|c|}
\hline \multirow[t]{2}{*}{ Variables } & \multicolumn{2}{|c|}{ Participant } & \multicolumn{2}{|c|}{$\begin{array}{l}\text { Non- } \\
\text { participant }\end{array}$} & \multicolumn{2}{|c|}{ Total } & \multirow[t]{2}{*}{ t-value } \\
\hline & Mean & SD & Mean & SD & Mean & SD & \\
\hline Distance from house to nearest market (km) & 7.54 & 4.33 & 12.22 & 4.25 & 9.87 & 4.89 & $-9.44^{* * *}$ \\
\hline Distance from house to main road (km) & 2.62 & 2.43 & 3.24 & 2.74 & 2.93 & 2.61 & -1.93 \\
\hline
\end{tabular}

*** indicates significance at $1 \%$ probability level.

Source: Compute from own survey, 2017. SD = standard deviation

Types of non-farm economic activities in the study area

For analytical purposes analyzing the types of non-farm activities is vital in order to discover the features of nonfarm activities in the study area. Though the economy of the household in the study area is depending on farming, substantial numbers of rural farm households are involved in non-farm activities to supplement farm income. Non-farm income is the income derived from source other than farming. As indicated in Table 7 below, rural farm households in the study area practiced different non-farm activities. More specifically, of the participant $33.84 \%$ engaged in selling Tela, Arequi, teji, soft drink, tea, bread, etc., $30 \%$ in retail shop, $18.46 \%$ selling wood and charcoal, $16.15 \%$ trade in grain general, $13.85 \%$ weaving, $12.31 \%$ boutique, and $9.23 \%$ craft work/carpentry, $7.7 \%$ trade in livestock, $6.15 \%, 4.62 \% 4.62 \%$, and $4.62 \%$ selling straw, transport by pack animal, pottery, and tailoring respectively. The remaining $10 \%$ of the rural farm households are engaged in other nonfarm activities (like butchery, selling raw food items and fruits, hair cutting, masonry, milling etc.) to supplement their farm income. 
Table 7: Types of non-farm activities

\begin{tabular}{|l|c|}
\hline \multicolumn{1}{|c|}{ Non-farm activities } & Percent \\
\hline \hline Selling of foods and drinks (Tela, Arequi, teji, soft drink, tea, bread, etc.) & 33.84 \\
\hline Retail shop & 30.00 \\
\hline Selling of wood and charcoal & 18.46 \\
\hline Trade in grain general & 16.15 \\
\hline Weaving & 13.85 \\
\hline Boutique & 12.31 \\
\hline Craft work/Carpentry & 9.23 \\
\hline Trade in Livestock & 7.70 \\
\hline Selling of straw & 6.15 \\
\hline Transport by pack animal & 4.62 \\
\hline Pottery & 4.62 \\
\hline Tailoring & 4.62 \\
\hline Others (butcher, selling raw food items and fruits, hair cutting, masonry, milling, etc.,) & 10.00 \\
\hline
\end{tabular}

N.B: Total percent exceed 100 percent due to multiple responses.

Source: Field Survey, 2017.

Factors that cause households to participate in non-farm activities

Participation by households in non-farm activities by rural households is caused by many factors. According to [3] rural households may decide to participate in non-farm activities in response to economic hardship or in response to emerging economic opportunities. Table 8 shows the factors that lead to households to decide to participate in the non-farm activities in the study villages. It shows that about $81.50 \%$ of households decide to engage in non-farm activities so that they can supplement low income earned from farming activities. Other factors include decline land size, soil fertility or productivity $(26.15 \%)$, growing family size $(20.77 \%)$, the presence of road, electricity and market in the village (9.23\%), seasonal nature of agricultural labor $(6.15 \%)$ and favorable demand for goods/services (5.38\%). Our study points, among others, the three main reasons that explain the extent and involvement in non-farm employments are insufficiency of income from farming activities, decline land size, soil fertility or productivity and growing family size. From this, one can observe that rural farm households in the area participated basically due to push factor.

Table 8: Factors that cause households to participate in non-farm activities

\begin{tabular}{|l|c|}
\hline Factors for Participation in Non-farm Activities & Percent \\
\hline \hline Insufficiency of income from farming activities & 81.50 \\
\hline Decline land size, soil fertility or productivity & 26.15 \\
\hline Growing family size & 20.77 \\
\hline Presence of road, electricity and market in the village & 9.23 \\
\hline Seasonal nature of agricultural labor & 6.15 \\
\hline Favorable demand for goods/services & 5.38 \\
\hline
\end{tabular}

N.B: Total percent exceed 100 percent due to multiple responses.

Source: Field Survey, 2017.

\subsection{Econometric results and discussions}

In order to identify the most important factors which determine farm household's decision to either participate in remunerative non-farm activities or not in the study area from the hypothesized potential variables, binary logistic regression model was used. The results from the logistic estimation are shown in Table 9. The most used measure of goodness of fit in maximum likelihood estimation is the likelihood ratio test statistic follows a chisquare distribution with 13 degrees of freedom and is significant at less than $1 \%$ significance level. It rejects the null hypothesis that all coefficients except the intercept are zero. The quality of prediction success indicates the number of sample observations correctly predicted by the model. The prediction success is based on the principle that if the estimated probability of the event is less than 0.5 , the event will not occur and if it is greater than 0.5 the event will occur [10]. The applied model correctly predicted $83.33 \%$ of the total sample rural farm households, $76.67 \%$ participant and $83.33 \%$ non-participant households in non-farm economic activities indicating the model predicts both groups fairly.

Among all the variables, the ones that significantly determine participation in remunerative non-farm activities are sex of household head, marital status of household head, dependency ratio, possession of special skill, access to credit and distance from the nearest market. All these mentioned variables are found in line with our a priori expectations. 
Sex of household head (sexhead): Sex of household head has a significant and negative effect on the probability of non-farm activities participation, and it is statistically at $1 \%$ significance level implying that female headed households are more likely participate in non-farm activities than the male, and this may be connected to the difficulties associated with farming or physical strength required in farming activities. Thus, females were found to be more likely to participate in rural non-farm activities in the study area.

Marital status of household head (married): Coefficient of marital status of household head was positive and significant at $1 \%$ implying that married headed households are more likely participate in non-farm activities. This is due to the fact that married headed households have relatively more labour power and might be motivated to allocate labour into non-farm activity.

Dependency ratio (depratio): Dependency ratio has a negative and significant coefficient (at 5\%), this imply that households with a large number of dependents relative to the number of adult households play a negative role in cash oriented non-farm activities. Thus, the existence of dependent persons impedes other household members from leaving the household and working outside. This result is consistent with the findings of [8].

Table 9: Logistic Regression Estimates for participation in non-farm activities

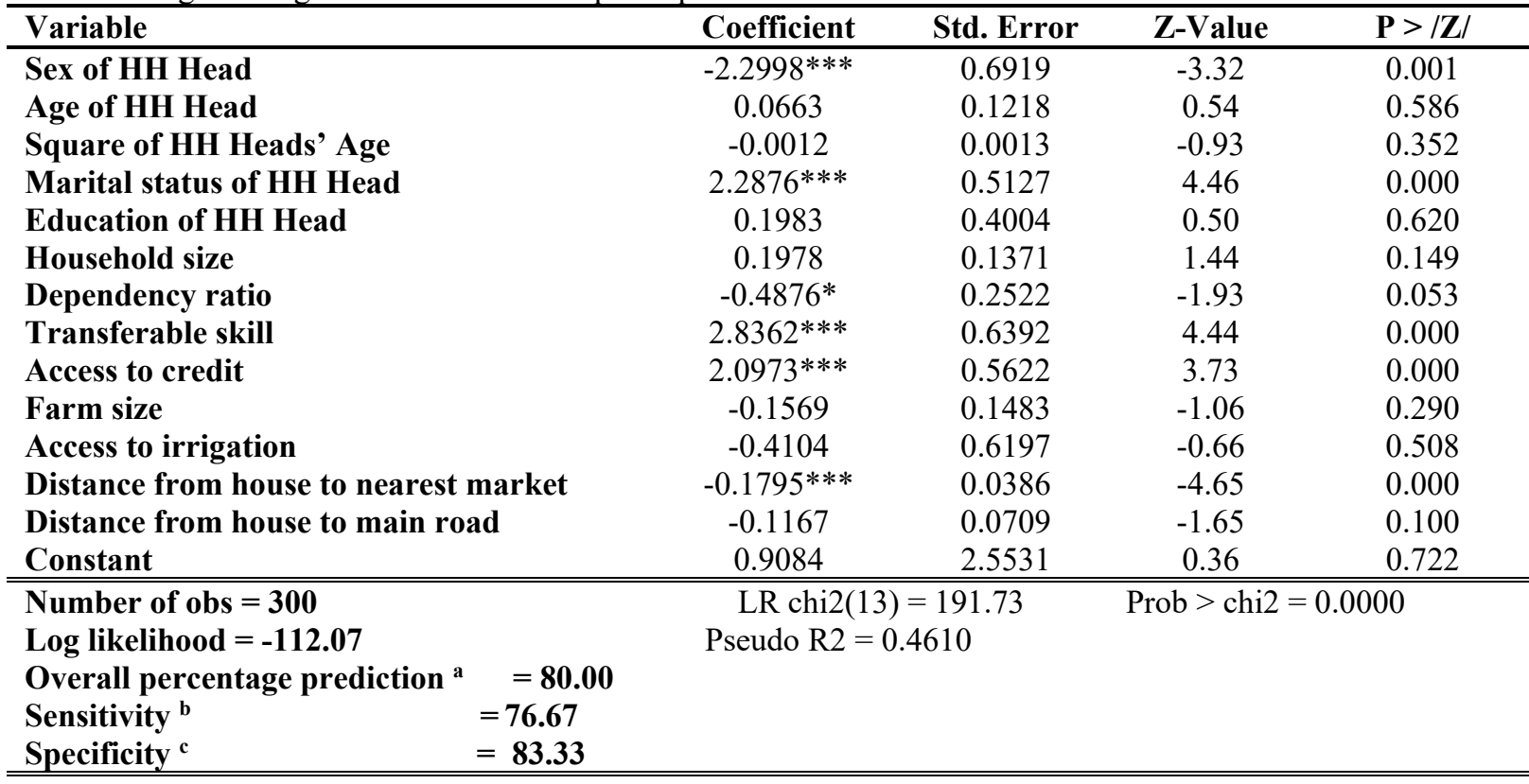

${ }^{\text {a }}$ Based on a 50-50 probability classification scheme.

${ }^{b}$ Correctly predicted participant groups based on a 50-50 probability classification scheme

c Correctly predicted non-participant groups based on a 50-50 probability classification scheme

$*, * *, * * *$ indicate significant at $10 \%, 5 \%$ and $1 \%$ probability level, respectively

Source: Compute from own survey, 2017

Special skill (skill): Possessing special skill has a significant and positive influence on the probability of non-farm activities participation, and it is statistically at 5\% significance level implying that skilled households are more likely to engage themselves in more paying non-farm activities. More specifically possessing skills such as masonry, handcrafts and merchants increase the probability of involvement in non-farm activities to the villages that are close the nearby towns while skills such as tannery, pot making, and goldsmith are associated to the villages that are far from towns. The skilled farm households have a positive interest in the involvement of non-farm activities in the study area. This may be because non-farm activities require some skills and training. Hence, households with some skill tended to engage in non-farm activities.

Access to credit (acccredit): Access to credit is found to be one of the major determinants of participation in non-farm economic activities. The coefficient of access to credit is positive and statistically significant at $1 \%$ significance level. Households with access to credit are more likely to participate in non-farm activities than those without access. Access to the credit market gives opportunities to farm households to get the necessary capital to start up or to be participated in non-farm employments. This positive relationship between non-farm activities participation and access to credit is similar to the finding of [14].

Distance from house to nearest market (dismkt): The coefficient of distance from the nearest market is negatively and statistically significant at $1 \%$ significance level, this shows that the nearer the distance to market the stronger the incentive to participate in non-farm activities. This is due the fact that the opportunities for labor market and less commuting cost. This is also similar to the study of [7]. 


\section{Conclusion and Recommendation}

\subsection{Conclusions}

This study was set out to analyze the determinants of participation in remunerative non-farm activities among rural farm households depending on the sample of 300 households drawn from five rural kebeles in Ambo district of west Shoa Zone, Oromia region, Ethiopia. Both descriptive analysis and econometric estimation results have been used to answer the stated key research questions. Based on the findings that were obtained from the study the following conclusion could be drawn.

The analysis demonstrated that the major non-farm occupational categories in which rural households engaged were selling of foods and drinks, retail shop, selling of wood and charcoal, trade in grain general, weaving, boutique, and craft work. The study has established that different factors lead households to participate in non-farm activities. They include low income from farming activities, land inadequacy, soil fertility or productivity, growing family size, and increased opportunities. These findings suggest that non-farm employment is a common feature of rural households in study area. The logistic result shows that participation in non-farm economic activities among rural farm households is significantly determined by gender, marital status, dependency ratio, specific skills, access to credit and distance from the nearest market. Thus, while this study is not advocating for non-farm economic activities as a substitute to farming, non-farm work could be a reliable complement to farming activities. Policy should therefore focus on enhancing participation of non-farm activities in the study area or in similar areas.

\subsection{Recommendations and Policy Implications}

This study has shed light on the determinants of rural farm household participation in remunerative non-farm activities in west Shoa zone of Ambo district, Oromia region, Ethiopia. Sex of household head, marital status of household head, dependency ratio, specific skills, access to credit and distance from the nearest market were identified as major determinants of household's participation in non-farm activities in rural setting. Based on the findings of the study, the following recommendations are made in an attempt to promote participation and performance of rural non-farm economic activities among rural farm households in the study area.

$>$ The result of the regression shows gender to be an important factor that determines participation in nonnonfarm activities. Accordingly, men rural farm households were less likely to participate in remunerative non-farm activities. Therefore, policy and programme that support rural men must pay greater attention to facilitating their access to rural non-farm activities in the study area. In general, encouraging easy entry into the non-farm sector by both males and females through improvement of human capital endowments and skill building.

$>$ Dependency ratio has a significant and negative effect on the probability of non-farm activities participation. This implies that households with a large number of dependents relative to the number of adult households play a negative role in cash oriented non-farm activities. Therefore, serious attention has to be given to limit the increasing population in the study area. Expanding the effective extension services to increase awareness among rural farm households in using family planning to limit the number of children in a household to get a healthy and productive family member that are both physically and financially strong to make decision.

$>$ A special skill positively and significantly influences the non-farm employment participation. Therefore, provision of skills training at local level specifically focused on building technical and managerial skills necessary to rural people, to enable them realize their potential and effectively undertake new types of activities.

$>$ Access to credit is found to be one of the major determinants of participation in non-farm economic activities. Improvement of rural micro-credit schemes so as to promote participation and performance of rural non-farm activities. To achieve this goal effectively, more emphasis should be placed on promotion of savings and credit schemes so as to build on the fact that most of participants in non-farm activities obtain their start-up capital from their own savings.

$>$ Moreover, distances from house to the nearest market has become the major determinant of involvement in non-farm economic activities. Thus, improving access to market facilities in rural areas by government and private developers are of paramount importance in the performance of rural non-farm activities. Community development association and non-governmental organization can also help on this issue.

\section{References}

[1] De Janvry, A. and Sadoulet, E. (2001). Income Strategies Among Rural Households in Mexico: The Role of Off-Farm Activities. World Development, 29(3):47-480.

[2] Ebaidalla M. Ebaidalla. (2014). Determinants of Farm Households' Participation in Non-farm Income Activities: Evidence from Rural Sudan. 
[3] Ellis, Frank. (2007). Strategic Dimensions of Rural Poverty Reduction in Sub-Saharan Africa. A Paper presented at the workshop: Rural Development Retrospect and Prospect: A Workshop for JudithHeyer Oxford, 14-15 September, 2007.

[4] Gesese and Ignatious. (2012). The Role of Off- and Non-Farm Activities in Achieving Sustainable Rural Livelihoods Security in Amhara Region, Ethiopia. Journal of Sustainable Development in Africa,Vol. 14, No.5, ISSN: $1520-5509$

[5] Hosmer, D.W., and S. Lemeshow, S. (1989). Applied Logistic Regression. University of Massachusetts and Amberst, Wiley-Inter Science Publication, New York. 307p.

[6] Huffman, W.E. (1991). Multiple jobholding among farm families. In: Agricultural Households Survey and Critique. Edited by J.L. Findeis, M.C. Hallberg and D.L. Lass. Chapter 5, Iowa State University Press, 1991, Ames IA, USA.

[7] Kassim, M. (2011). Determinants of Participation in Non-farm Economic Activities in Rural Zanzibar; African Centre for Food Security, School of Agricultural Science and Agribusiness, Faculty of Science and Agriculture, University of KwaZulu-Natal, Pietermaritzburg

[8] Lanjouw, J.O. and Lanjouw, P. (2001). The Rural Non-farm Sector: Issues and Evidence from Developing Countries. Agricultural Economics 26(1): 1-23.

[9] Lanjouw, P. and Sharrif, A. (2002). Rural Non-Farm Employment in India: Access, Income and Poverty Impact, Working Paper Series No. 81.

[10] Maddala, G.S. (1992). Introduction to Econometrics. Second Edition. USA: Prentice-Hall,Inc.

[11] Mduma, J., Wobst, P. (2005). Determinants of Rural Labor Market Participation in Tanzania Volume 8, Issue 2

[12] Mishra, A. and Goodwin, B. (1997). Farm Income Variability and the Supply of Off farm Labour. American Journal of Agricultural Economics, 79: 880-887.

[13] Mulatu, D. (2001). Off-farm income generation in Ethiopia: Opportunities and constraints in food-insecure Weredas of Oromiya and Amhara Regional States', Ethiopian Development Forum', 2, (1), 22-45.

[14] Reardon, T., Berdague, J., and Escobar, G. (2001). Rural Nonfarm employment and Incomes in Latin America: Overview and Policy Implications. World development 29, 395-409.

[15] Reardon, T., Berdegué, J., Barrett, C.B. and Stamoulis, K. (2006). Household income diversification into rural non-farm activities. In: Transforming the Rural Non-farm Economy.

[16] Woldehanna, T. (2000). Economic analysis and policy implications of farm and off-farm employment: a case study in the Tigray Region of Northern Ethiopia. 